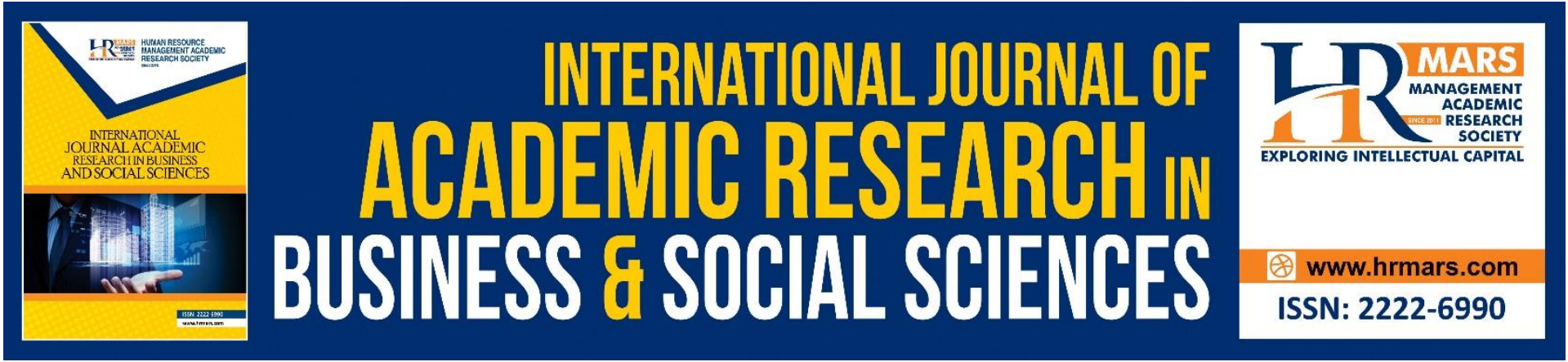

\title{
Performance in Professional Courses as Predictor of Psychometrician Licensure Examination (PMLE) of Psychology Graduates From a Private University in the Philippines
}

\section{Nonet A. Cuy}

To Link this Article: http://dx.doi.org/10.6007/IJARBSS/v11-i5/10022

DOI:10.6007/IJARBSS/v11-i5/10022

Received: 05 April 2021, Revised: 28 April 2021, Accepted: 17 May 2021

Published Online: 29 May 2021

In-Text Citation: (Cuy, 2021)

To Cite this Article: Cuy, N. A. (2021). Performance in Professional Courses as Predictor of Psychometrician Licensure Examination (PMLE) of Psychology Graduates From a Private University in the Philippines. International Journal of Academic Research in Business and Social Sciences, 11(5), 684-691.

Copyright: @ 2021 The Author(s)

Published by Human Resource Management Academic Research Society (www.hrmars.com)

This article is published under the Creative Commons Attribution (CC BY 4.0) license. Anyone may reproduce, distribute, translate and create derivative works of this article (for both commercial and non-commercial purposes), subject to full attribution to the original publication and authors. The full terms of this license may be seen at: http://creativecommons.org/licences/by/4.0/legalcode

Vol. 11, No. 5, 2021, Pg. 684 - 691

Full Terms \& Conditions of access and use can be found at http://hrmars.com/index.php/pages/detail/publication-ethics 


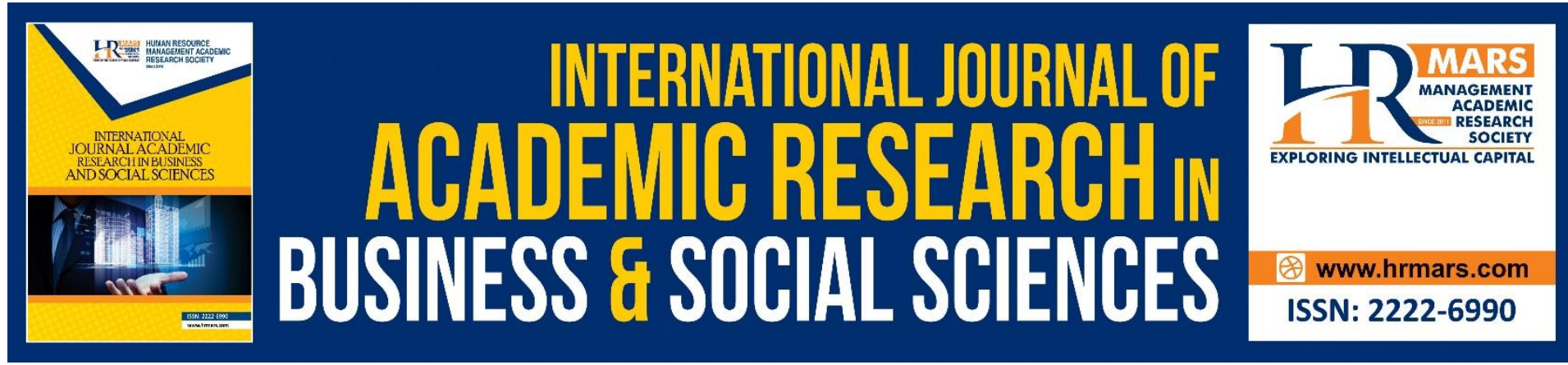

\title{
Performance in Professional Courses as Predictor of Psychometrician Licensure Examination (PMLE) of Psychology Graduates From a Private University in the Philippines
}

\author{
Nonet A. Cuy \\ Faculty, College of Arts and Sciences University of Perpetual Help System Laguna Laguna, \\ Philippines \\ Email: cuy.nonet@uphsl.edu.ph
}

\begin{abstract}
This study aimed at determining the performance of BA/BS Psychology graduates in professional courses as predictor of Psychometrician licensure examination. This descriptivecorrelational study involved 104 psychology graduates from academic year 2015-2018 of the University of Perpetual Help System Laguna, Binan Campus. Findings showed that majority of the respondents had a satisfactory grade in professional courses. Nearly half of them passed the licensure examination. A significant relationship was noted between the respondents' academic performance in professional courses along Psychological assessment $(p=0.005)$, Abnormal psychology $(p=0.000)$ and Industrial psychology $(p=0.000)$ and their Psychometrician licensure examination. Among the professional courses included in the licensure examination Abnormal psychology was found to be a good predictor of their Psychometrician licensure examination which may be attributed to teacher's competence in teaching the course, effective instruction and quality of education that reflects the school efficiency.
\end{abstract}

Keywords: Descriptive Correlational Study, Professional Courses, Psychometrician Licensure Examination, Psychology Graduates

\section{Introduction}

The Professional Licensure Examination served as a means of sustaining the quality of professionals after they had been trained and schooled in their institution. The licensure examination is one of the tools that evaluates and ensure the nature of graduates that will join the workforce of various company locally and globally. It has become an essential step in assuring that one has met the qualifications to practice in a particular area of specialization

The Philippine Psychology Act of 2009 (Republic Act, 10029) was signed into law with its purpose to regulate the professional practice of psychology and psychometrics in the Philippines for the protection of the public from inexperienced and untrained individuals 
offering psychological services; to ensure that psychologists are competent, excellent and globally competitive.

Passing a licensure examination given by the Professional Regulation Commission (PRC) is considered one of the best accomplishments of the student in his life. This examination is design to measure the students' knowledge, competency, skills and attitude in the practice of their respective profession as stated by Mohammed and Mohammed (2017). The academic institutions offering degree programs with board examination is responsible and accountable for the success of their graduates. This can be done by means of quality instruction and experiences of the members in the academic system as prerequisites for licensure. The success of an institution can be measured through the performance of its graduate in the licensure examination. As stated by Manalo and Obligar (2013), the performance of the graduates in the licensure examination manifests the school's efficacy and intellectual capability of the graduates.

Several studies found out that academic performance of the students influences licensure examination performance (Nyangena, et al., 2013; Hena, et al., 2014; Rabanal, 2016; Barlis \& Fajardo, 2015; De Leon, 2016; Pascua \& Navalta, 2011). Furthermore, Dagdag et al., (2017) revealed that the examinees' academic performance in General education, Professional education and Major had significant impact on their LET performance which confirmed that the examinees with higher general weighted average (GWA) scored higher in LET. However, in the study conducted by Pachejo \& Allaga (2014) on the academic predictors of the licensure examination for teachers' performance a moderate correlation was noted in general education. But when LET performance was correlated with professional education and specialization, a slight correlation was found. This indicates that professional education and specialization cannot predict LET examination. In addition, Manalo and Obligar (2013) said that passing a licensure examination needs patience, determination, support, encouragement and prayers.

The PNU Psychology majors who took the 2014 to 2016 PmLE established a decrease from $63.16 \%$ to $45.65 \%$ of the university passing rate. This may indicate a poor performance raring with the increase of the examinees (Obias, 2018). Likewise, the UPHSL-Binan Campus psychology majors who took the August 2016, October 2017 and October 2018 PmLE established a decrease in the overall passing percentage from $35.29 \%$ to $25.42 \%$.

From the perspectives mentioned by the experts in the fields considering the variables understudy, the researcher aimed at determining the performance of the psychology graduates on professional courses as predictor of Psychometrician licensure examination. Specifically, it sought answers to the following sub problem:

- What are the respondents' academic performance in professional courses?

- What is the respondents' performance in the Psychometrician licensure examination?

- How does the respondents' academic performance in professional courses relate to their performance in the Psychometrician licensure examination?

- How predictive are the respondents' academic performance in professional courses, taken singly or in combination of the Psychometrician licensure examination? 
This study considered Attribution theory by Weiner (Praven, 2017) which focused on achievement. He identified ability, effort, task difficulty and luck as the most important factors affecting attributions for achievement. This theory undertakes with how individual interpret events and how this may relate to their thinking and behavior. It assumes that individuals try to determine why individuals do what they do. In general, when an individual succeeds, they are likely to attribute this success to their own effort or ability; but when they fail, they attribute their failure to other factors in which they do not have control.

\section{Materials and Methods}

The present study was conducted at the University of Perpetual Help System Laguna, City of Binan. The researcher utilized descriptive-correlational design and random sampling technique in determining the target respondents of one hundred four (104) out of one hundred forty psychology graduates who took Psychometrician licensure examination. The researcher considered the academic grades of the respondents in professional courses included in the Psychometrician licensure examination namely: Psychological Assessment, Abnormal Psychology, Industrial Psychology and Theories of Personality.

The researchers asked permission from the Dean of the College of Arts and Sciences before the actual gathering of data. Upon the approval of the request, the researcher personally collected the needed data, tallied and tabulated for statistical analysis using SPSS. Appropriate statistical tools were utilized in answering the problems such as frequency and percentages to determine the respondents' academic performance in professional courses and their performance in the Psychometrician licensure examination. Correlation coefficient was utilized to determine the relationship between the respondents' academic performance in professional courses and their performance in the Psychometrician licensure examination. Stepwise Regression was also used to determine which variable/s predicts Psychometrician licensure examination.

\section{Results and Discussion}

The performance of the respondents in professional courses, licensure examination and the correlation of the abovementioned variables are presented in the succeeding discussions.

Table 1

The Respondents' Academic Performance in Professional Courses

\begin{tabular}{|c|c|c|c|c|c|c|c|c|c|c|}
\hline \multirow{2}{*}{ Grade } & \multicolumn{2}{|c|}{$\begin{array}{c}\text { Psychological } \\
\text { Assessment }\end{array}$} & \multicolumn{2}{c|}{$\begin{array}{c}\text { Abnormal } \\
\text { Psychology }\end{array}$} & \multicolumn{2}{c|}{$\begin{array}{c}\text { Industrial } \\
\text { Psychology }\end{array}$} & \multicolumn{2}{c|}{$\begin{array}{c}\text { Theories of } \\
\text { Personality }\end{array}$} & \multicolumn{2}{|c|}{$\begin{array}{c}\text { Overall } \\
\text { Performance }\end{array}$} \\
\cline { 2 - 13 } & $\mathbf{F}$ & $\%$ & $\mathbf{F}$ & $\%$ & $\mathbf{F}$ & $\%$ & $\mathbf{F}$ & $\%$ & $\mathbf{F}$ & $\%$ \\
\hline $95-99$ & 3 & 2.88 & 2 & 1.92 & 1 & 0.96 & 4 & 3.85 & - & \\
\hline $90-94$ & 28 & 26.92 & 17 & 16.35 & 19 & 18.27 & 26 & 25.00 & 20 & 19.23 \\
\hline $85-89$ & 49 & 47.11 & 44 & 42.31 & 49 & 47.11 & 39 & 37.50 & 53 & 50.96 \\
\hline $80-84$ & 22 & 21.15 & 33 & 31.73 & 27 & 25.96 & 25 & 24.04 & 27 & 25.96 \\
\hline $75-79$ & 2 & 1.92 & 8 & 7.69 & 8 & 7.69 & 10 & 9.61 & 4 & 3.85 \\
\hline Total & 104 & 100.00 & 104 & 100.00 & 104 & 100.00 & 104 & 100.00 & 104 & 100.00 \\
& & & & & & & & & & \\
\hline
\end{tabular}


As shown in Table 1, two of the respondents (2) got a grade of 75-79 for Psychological assessment, eight (8) for Abnormal and Industrial psychology, and ten (10) for Theories of personality. Twenty-two (22) of them got 80-84 for Psychological assessment, thirty-three (33) for Abnormal psychology, twenty-seven (27) for Industrial psychology and twenty- five (25) for Theories of personality.

Nearly half of the respondents got 85-89 for Psychological assessment, Industrial psychology (47.11\%) and Abnormal psychology (42.31\%); thirty-nine (39) for Theories of personality. Thirty-one (31) got a grade ranges from 90-99 for Psychological assessment, nineteen (19) for Abnormal psychology, twenty (20) for Industrial psychology and thirty (30) for Theories of personality.

Overall performance of the respondents revealed that more than half of them (53) got a grade of 85-89. Twenty (20) or 19.23 percent got 90-94. Twenty-seven (27) got 80-84 and only four (4) of them got a grade of 75-79. In general, majority of the respondents had a satisfactory grade in professional courses.

Table 2

The Respondents' Performance in the Psychometrician Licensure Examination

\begin{tabular}{|c|c|c|c|c|c|c|c|c|c|c|}
\hline \multirow[t]{2}{*}{ Grade } & \multicolumn{2}{|c|}{$\begin{array}{l}\text { Psychological } \\
\text { Assessment }\end{array}$} & \multicolumn{2}{|c|}{$\begin{array}{l}\text { Abnormal } \\
\text { Psychology }\end{array}$} & \multicolumn{2}{|c|}{$\begin{array}{l}\text { Industrial } \\
\text { Psychology }\end{array}$} & \multicolumn{2}{|c|}{$\begin{array}{l}\text { Theories of } \\
\text { Personality }\end{array}$} & \multicolumn{2}{|c|}{$\begin{array}{l}\text { Overall } \\
\text { Performance }\end{array}$} \\
\hline & $\mathbf{F}$ & $\%$ & $\mathbf{F}$ & $\%$ & $\mathbf{F}$ & $\%$ & $\mathbf{F}$ & $\%$ & $\mathbf{F}$ & $\%$ \\
\hline $85-89$ & - & & 11 & 10.58 & 3 & 2.88 & - & & - & \\
\hline $80-84$ & 17 & 16.35 & 34 & 32.69 & 22 & 21.15 & 3 & 2.88 & 11 & 10.58 \\
\hline $75-79$ & 46 & 44.23 & 32 & 30.77 & 44 & 42.31 & 31 & 29.81 & 37 & 35.58 \\
\hline Below 75 & 41 & 39.42 & 27 & 25.96 & 35 & 33.65 & 70 & 67.31 & 56 & 53.85 \\
\hline Total & 104 & 100.00 & 104 & 100.00 & 104 & 100.00 & 104 & 100.00 & 104 & 100.00 \\
\hline
\end{tabular}

As shown in Table 2, only eleven (11) of the respondents got a grade of 85-89 for Abnormal psychology and three (3) for Industrial psychology. Seventeen (17) got 80-84 for Psychological assessment, Thirty-four (34) for Abnormal psychology, Twenty-two (22) for Industrial psychology and only three (3) for Theories of personality. Forty-six (46) got 75-79 for Psychological assessment, thirty-two (32) for Abnormal psychology, forty-four (44) for Industrial psychology and thirty-one (31) for Theories of personality. Forty-one (41) got below 75 for Psychological assessment, twenty-seven (27) for Abnormal psychology, thirty-five (35) for Industrial psychology and majority of them (70) for Theories of personality.

Overall performance of the respondents in the Psychometrician licensure examination revealed that more than half of them $(53.85 \%)$ failed in the licensure examination. Thirtyseven (37) or 35.58 percent got 75-79 and eleven (11) or 10.58 percent got 80-84. In general, most of them did not perform well in the Psychometrician licensure examination. 
Table 3

Relationship between the Respondents' Academic Performance in Professional Courses and their Psychometrician Licensure Examination

\begin{tabular}{|l|c|c|c|}
\hline Professional Courses & Pearson r value & p-value & Interpretation \\
\hline Psychological Assessment & $\begin{array}{c}0.277 \\
\text { Low correlation }\end{array}$ & $0.005^{*}$ & Significant \\
\hline Industrial Psychology & $\begin{array}{c}0.436 \\
\text { Moderate } \\
\text { correlation }\end{array}$ & $0.000^{*}$ & Significant \\
\hline Theories of Personality & $\begin{array}{c}0.380 \\
\text { Low correlation } \\
\text { correlation }\end{array}$ & $0.000^{*}$ & Significant \\
\hline Overall & $\begin{array}{c}0.422 \\
\text { Moderate } \\
\text { correlation }\end{array}$ & $0.000^{*}$ & Significant \\
\hline *Significant @ 0.01 & \multicolumn{2}{|l}{} \\
\hline
\end{tabular}

As reflected in Table 3, a significant relationship was noted between the respondents' academic performance in professional courses along Psychological assessment $(p=0.005)$, Abnormal psychology $(p=0.000)$ and Industrial psychology $(p=0.000)$ and their Psychometrician licensure examination. The probability values were all less than the significance level of 0.01. This means that the respondents who have better and higher academic performance in professional courses such as Psychological assessment, Industrial psychology and Abnormal psychology scored higher in psychometrician licensure examination. This result was the same with the study conducted by several researchers (Hena et al., 2014; Rabanal, 2016; De Leon, 2016) that academic performance is a good predictor of licensure examination performance.

However, the respondents' academic performance in Theories of personality was not related to their performance in Psychometrician licensure examination. The probability value of 0.320 was greater than the 0.05 significance level. This implies that the respondents' performance in the Psychometrician licensure examination had nothing to do with their performance in Theories of personality. The result may be ascribed to the study conducted by Villaluz (n.d.) that the level of competence of the students on Theories of Personality has nothing to do with their readiness of taking the licensure examination for psychometrician. This indicates that whether the students acquired all the competencies needed so long as they are determined and have faith in God. 
Table 4

Stepwise Regression Analysis on Predictors of Psychometrician Licensure Examination

\begin{tabular}{|l|l|l|l|l|l|l|l|l|}
\hline $\begin{array}{l}\text { Dependent } \\
\text { Variable }\end{array}$ & $\begin{array}{l}\text { Model } \\
\text { (Predictor) }\end{array}$ & $\mathrm{R}$ & $\mathrm{R}^{2}$ & $\begin{array}{l}\text { Adjusted } \\
\mathrm{R}^{2}\end{array}$ & $\begin{array}{l}\text { Sig. } \\
\text { Change }\end{array}$ & $\beta$ & $\mathrm{t}$ & Sig. \\
\hline $\begin{array}{l}\text { Average } \\
\text { board } \\
\text { performance }\end{array}$ & $\begin{array}{l}\text { Abnormal } \\
\text { psychology }\end{array}$ & 0.459 & 0.211 & 0.203 & 0.000 & 0.624 & 5.194 & 0.000 \\
\hline
\end{tabular}

As shown in Table 4 for the stepwise regression on predictors of Psychometrician licensure examination, it was reflected that only academic performance in Abnormal psychology was found to be significantly correlated $(r=0.459)$, and this variable explained $20.30 \%$ of the total variance in average board performance grade. The $t$ value of 5.194 with probability value of 0.000 indicated that Abnormal psychology affects their performance in Psychometrician licensure examination. This implies that Abnormal psychology is the principal predictive variable and predictor of Psychometrician licensure examination.

This result is similar to the study conducted by Ong and Palompon (2012) which states that college GPA was the principal predictive variable of licensure examination that viewed students' learning in the classroom and clinical exposure predicted their performance in the licensure examination.

\section{Conclusions and Recommendations}

After analyzing the significant findings, the following conclusions were drawn: majority of the respondents had a satisfactory grade (85-89) in professional courses. Fortyeight of them passed the Psychometrician licensure examination with a grade between 75 and 84. A significant correlation was noted between the respondents' academic performance in professional courses along Psychological assessment $(p=0.005)$, Abnormal psychology $(p=0.000)$ and Industrial psychology $(p=0.000)$ and their Psychometrician licensure examination. Abnormal psychology was found to be a predictor of Psychometrician licensure examination.

Thus, results substantiate the theory that the quality of the curriculum is introspective of the quality of instruction given to the students. The readiness of the psychology graduates to take the licensure examination is largely influenced by the learning institution. Also, a continuous review and assessment of the curriculum and courses will aid in strengthening the program thereby making psychology graduates ready for licensure examination.

Since most of the respondents failed in Theories of Personality as one of the board courses in Psychometrician licensure examination, teachers handling this course may be required to take a double-look at their teaching strategies and content through modification and enhancement of syllabus, activities and the manner of test questions in the actual licensure examination to maximize students learning. The College of Arts and Sciences may consider adopting a qualifying examination to students before their final year to ascertain their strengths and weaknesses. The College may conduct in-house review and pre-board examination to ensure students success in the Psychometrician licensure examination. 
Further, considering the limitations of this study, it is recommended that in the future studies using different variables may be added such as teachers' profile, teaching strategies may also contribute to students' academic performance as well as licensure examination.

\section{References}

Barlis, J., \& Fajardo, J. (2015). Predictors of performance of the Maritime Academy of Asia and the Pacific (MAAP) in the OIC navigational watch licensure examination. Journal of Shipping and Ocean Engineering, 5(2), 88-101. https://doi.org/ 10.17265/21595879/2015.02.005

Dagdag, J. D., Sarmiento, C. S., \& Ibale, J. C. (2017). Examining the factors of licensure examination for teacher performance for program strategy enhancement. Asia Pacific Journal of Multidisciplinary Research, 5(4), 34-39.

De leon, J. (2016). Academic and licensure examination performance of BSN graduates: Bases for curriculum enhancement. International Journal of Educational Policy Research and Review. 3(4), 64-72.

Hena, R., Ballado, R., Dalucapas, M., Ubane, S., \& Basierto, R. (2014). Variates of the Performance of Teacher Education Graduates in the Licensure Examination for Teachers (LET). International Journal of Interdisciplinary Research and Innovations, 2(4), 157-163.

Manalo, M. C., \& Obligar, M. (2013). Correlation of the LPU-Batangas Mock Board Examination and Customs Broker Licensure Examination for Academic Year 20082010. Proceeding of the Global Summit on Education. Available from http://goo.gl/n7NtOD.

Mohammed, M. P., \& Mahammed, M. P. (2017). Licensure Examination Performance Evaluation of the Candidate Engineers as Basis for a Proposed Action Plan. Asia Pacific Journal of Multidisciplinary Research, 5(2), 51-57.

Nyangena, E., Getanda, A., \& Ngugi, S. (2013). Factors Influencing Success of Bachelor of Science in Nursing Graduates in Nursing Council of Kenya Licensure Examinations. Baraton Interdisciplinary Research Journal, 3(1), 11-21.

Obias, P. H. R. (2018). The Psychometrician Licensure Examinations (PmLE): Impact to the Behavioral Science Curriculum. The Normal Lights, 12(2), 124-144.

Pachejo, S. J., \& Allaga, W. A. (2014). Academic Predictors of the Licensure Exam for Teachers' Performance of RTU's Teacher Education Graduates. Asia Pacific Higher Education Research Journal (APHERJ), 1(1), 71-90. Retrieved from http: www. po.pnuresearchportal.org/ejournal/index.php/apherj/article/view/81.

Pascua, J., \& Navalta, J. (2011). Determinants of LET Performance of the Teacher Education Graduates in a State University. JPAIR Multidisciplinary Journal, 6, 90-102.

Praven, S. (2017). "Attribution Theory" in Psychestudy. Retrieved from http://www.psychestudy.com/social/attribution-theory.

Rabanal, G. (2016). Academic Achievement and LET Performance of the Bachelor of Elementary Education Graduates, University of Northern Philippines. International Journal of Scientific and Research Publications, 6(6), 455-461.

Villaluz, S. (n.d.). Degree of Inclination, Board Course Competence and Licensure Readiness among UPHSL Psychology Graduates. Retrieved from:

https://www.uphsl.edu.ph/research/ARTS\%20_\%20SCIENCES/VILLALUZ,\%20Sherill\% 20S/Degree\%20of\%20Inclination,\%20Board\%20Course\%20Competence,\%20and\%20 Licensure\%20Readiness\%20among.pdf 